Original article. January-April 2018; 8(1):47-52. Received: 2017 /05/21 Accepted: 2017/08/11.

http://dx.doi.org/10.21929/abavet2018.81.4

\title{
Identificación de los principales parásitos gastrointestinales en burros del Valle de Tulancingo
}

\author{
Identification of main gastrointestinal parasites in donkeys of Tulancingo Valley
}

\author{
Rivero-Perez Nallely* oiz372003@hotmail.com, Zaragoza-Bastida Adrian \\ adrianzb1982@hotmail.com, Vega-Sánchez Vicente vicentevgsa@yahoo.com.mx, Olave- \\ Leyva Ignacio jose_olave6083@uaemex.edu.mx, Vega-Angeles Jesús \\ jevean2004@gmail.com, Peña-Jiménez Francisco** fjpenj@hotmail.com
}

1 Universidad Autónoma del Estado de Hidalgo. Instituto de Ciencias Agropecuarias. Tulancingo de Bravo, Hidalgo. Mexico. *Author responsible: Rivero-Perez Nallely. ${ }^{* *}$ Author of correspondence: Peña-Jiménez Francisco. Rancho Universitario. Av. Universidad Km. 1. Ex Hacienda Aquetzalpa, Apartado Postal No. 32, Tulancingo de Bravo, Hidalgo. México.

\section{RESUMEN}

Los burros (Equus africanus asinus) al igual que el resto de las especies animales, son susceptibles a la infestación por ecto y endoparásitos, las investigaciones con respecto a las parasitosis que afectan a esta especie son muy escasa y se asume que la signología, patogenia, tratamiento y control, son similares a los observados en los caballos. El objetivo de la presente investigación fue identificar las principales especies de parásitos gastrointestinales en burros del Valle de Tulancingo. Se utilizaron 11 burros con una edad promedio de dos años, los cuales fueron manejados de acuerdo a las normas bioéticas internacionales. Se colectaron muestras de heces, las muestras fueron procesadas para observar la morfología de los huevos de parásitos gastrointestinales, así como la cuantificación de los mismos por medio de la técnica de flotación y Mc Master respectivamente. El 100\% de los burros presentaron huevos de parásitos gastrointestinales, el 91\% (10/11) de los animales estudiados presentaron Trichostrongylus spp, el $64 \%$ (7/11) presentó Strongylus ssp, el 36\% (4/11) Trichonema spp, el 27\% (3/11) Parascaris equorum, Strongyloide westeri, el 9\% (1/11) Anaplocephala spp y Oxyuris equi. Se determinó que Trichostrongylus spp, es el parásito gastrointestinal predomínate en burros del Valle de Tulancingo.

Palabras clave: Equus africanus asinus, Oxyuris equi, Parascaris equorum, Strongyloides, Thrichonema, Strongylus.

\section{ABSTRACT}

The donkeys (Equus africanus asinus), like the rest of the animal species are susceptible to infestation by ecto and endoparasites, the investigations with respect to parasitism that affect this species are very scarce and it is assumed that symptoms, pathogeny, treatment and control are similar to those observed in horses. The aim of the present investigation was to identify the main species of gastrointestinal parasites in donkeys of Tulancingo Valley. Eleven donkeys with an average age of two years were used which were managed according to international bioethical standards. Feces were collected and processed to observe the eggs morphology of gastrointestinal parasites and quantification the eggs by flotation and Mc Master techniques respectively. The $100 \%$ of donkeys presented eggs of gastrointestinal parasites, $91 \%(10 / 11)$ presented Trichostrongylus spp, 64\% (7/11) Strongylus spp, 36\% (4/11) Trichonema spp, 27\% (3/11) Parascaris equorum, Strongyloide westeri, 9\% (1/11) Anaplocephala spp and Oxyuris equi. It was determined that Trichostrongylus spp is the main gastrointestinal parasite in donkeys of Tulancingo Valley.

Keywords: Equus africanus asinus, Oxyuris equi, Parascaris equorum, Strongyloides, Thrichonema, Strongylus. 


\section{INTRODUCTION}

The donkeys (Equus africanus asinus), like the rest of the animal species are susceptible to the infestation by ecto and endoparasites, the investigations with respect to the parasitism that affect this species are very scarce and it is assumed that the signs, pathogeny, treatment and control are very similar to those observed in horses (Svendsen et al., 1997).

Among the endoparasites that can affect the donkeys are the gastrointestinal helminths, pulmonary worms and flatworms or fasciolas, being the gastrointestinal helminths, the most frequent; which cause different clinical manifestations ranging from diarrhea to anemia and even death. The severity of the signology will depend on the age, nutritional status and resistance of the donkey, as well as on the parasite involved and the degree of infestation (Svendsen et al., 1997, Matthews J. B, 2014).

The gastrointestinal helminths that most frequently affect donkeys are ascarids (Parascaris equorum), large nematodes (Strongylus spp), small nematodes (Thrichonema spp), pinworm (Oxyuris equi) and the roundworms (Strongyloides), with nematodes being the most difficult to treat because of the degree of resistance to anthelmintics (Svendsen et al., 1997, Matthews, 2014).

The diagnosis of gastrointestinal parasitic diseases caused by different types of gastrointestinal nematodes is performed by means of coproparasitoscopic examinations, which consists in observing the presence and morphology of larvae and eggs, as well as the quantification of the latter to determine the parasitic load. Depending on the parasitic load species, it is possible to determine if it is pertinent or not to perform a deworming, the presence of 50 to 450 eggs per gram of feces $(\mathrm{HGH})$ is considered a low burden and therefore no pharmacological treatment is required. However, the presence of more than $1000 \mathrm{HGH}$ is considered a high burden, which will require the implementation of a deworming program (Svendsen et al., 1997).

In addition to coproparasitoscopic analysis it is important to consider that in order to have a correct diagnosis regarding parasitosis it is necessary to combine them with clinical signs (weight loss, lethargy, depression, diarrhea, severe cases of colic and fever) and complementary tests such as hemogram and blood biochemistry (Svendsen et al., 1997, Cribb et al., 2006). Therefore the objective of the present investigation was to identify the main species of gastrointestinal parasites in donkeys of the Valley of Tulancingo 


\section{MATERIAL AND METHODS}

\section{Animals}

In the present experiment, 11 clinically healthy donkeys (Equus africanus asinus) were used, $55 \%(6 / 11)$ were males and $45 \%$ females (5/11), with an average weight of 85 kilograms ( $85 \pm 12.4)$ and an average age of two years $(2 \pm 0.5)$ which was calculated by dental wear. During the evaluation period the animals were managed according to international bioethical standards, to provide them with the comfort conditions they require and thus avoid stressful situations. They were provided with free access water and quality food that covered their nutritional requirements.

\section{Identification and quantification of parasites}

Stool samples were collected directly from the rectum of the animals, which were transported to the Laboratory of Parasitology Research of the Veterinary Medicine and Animal Science Academic Area (AAMVZ), at the Institute of Agricultural Sciences (ICAp according its acronyms in Spanish) of the Autonomous University of Hidalgo State (UAEH), for analysis.

The feces (approximately 10 to 20 grams) were placed in ziploc hermetic plastic bags, which were stored at $4{ }^{\circ} \mathrm{C}$ from collection until processing, which was carried out in a period of no more than 12 hours. Samples were examined by qualitative flotation technique in saturated $\mathrm{NaCl}$ solution to observe the presence of helminth eggs in the microscope (Motic Ba310) and quantification was performed by the Mc Master technique (Besné et al., 2006) .

\section{RESULTS AND DISCUSSION}

The donkeys of the Tulancingo Valley presented a $100 \%(11 / 11)$ prevalence of gastrointestinal parasites, a result similar to that published by Bedoya et al. in 2011 who determined a $92 \%$ prevalence of gastrointestinal parasites on horses (Bedoya et al., 2011). On the other hand, Francisco and collaborators in 2009 mention that the parasitic infections of greater prevalence are those caused by gastrointestinal helminths, especially strongyloides and, to a lesser extent, ascarids and pinworm.

In the present investigation, $91 \%(10 / 11)$ of the animals studied presented release of Trichostrongylus spp eggs, 64\% (7/11) presented Strongylus spp, 36\% (4/11) Trichonema spp, 27\% (3/11) Parascaris equorum, Strongyloide westeri, 9\% (1/11) Anaplocephala spp and Oxyuris equi as seen in Figure 1 and Table 1. 


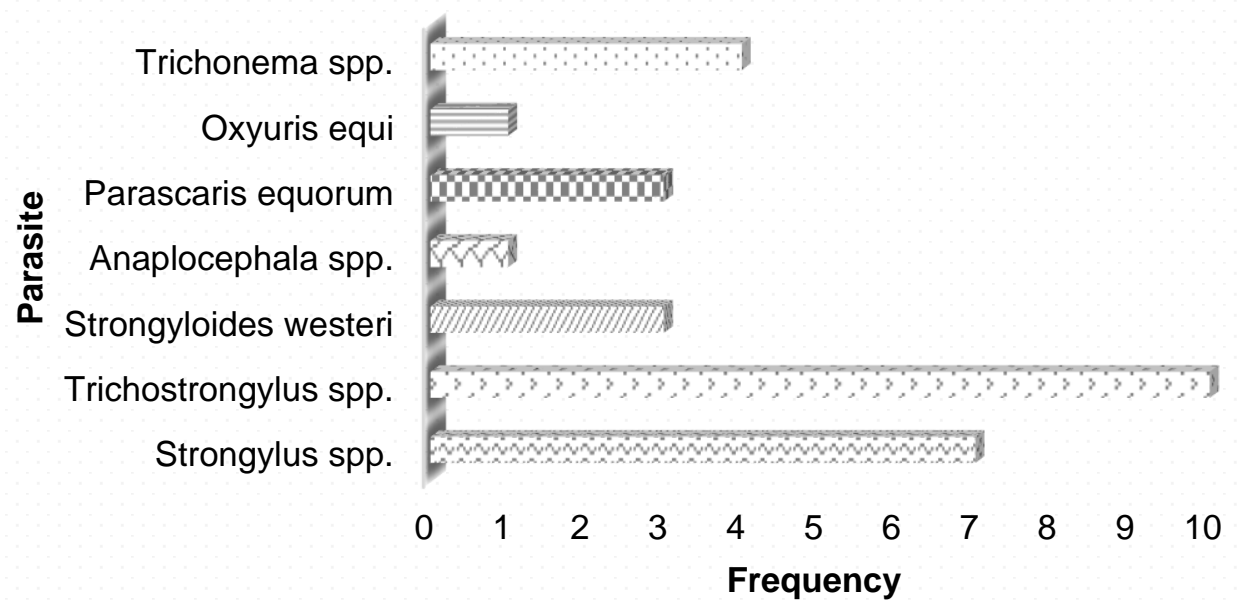

Figure 1. Frequency of gastrointestinal parasites in donkeys in the Tulancingo Valley

Table 1. Frequency of gastrointestinal parasitism in donkeys in the Tulancingo Valley

\begin{tabular}{lcc}
\hline \multicolumn{1}{c}{ Parasite } & Percentage \% & Average eggs per gram of faeces \\
\hline Strongylus spp. & 64 & 1920 \\
Trichostrongylus spp. & 91 & 1800 \\
Strongyloides westeri & 27 & 1612 \\
Anaplocephala spp. & 9 & 1000 \\
Parascaris equorum & 27 & 300 \\
Oxyuris equi & 9 & 200 \\
Trichonema spp. & 36 & 150 \\
\hline
\end{tabular}

In Figure 1 it can be observed that the predominant nematode in the sampling was Trichostrongylus spp with $91 \%$ followed by Strongylus spp with $64 \%$, which are associated with ulcerative gastric disorders, results that agree with Matthews and collaborators in 2013 who propose that the Strongyloides spp are the most important parasites in donkeys in the United Kingdom (Matthews et al., 2013). Cardona and colleagues in 2015 determined that $56.9 \%$ of the donkeys under evaluation had gastric ulcers associated with Trichostrongylus axei (Cardona et al., 2015).

Bedoya and collaborators in 2011 determined a 92\% prevalence of Trichostrongylus spp in horses (Bedoya et al., 2011).

In the present experiment, eggs of Strongylus spp, Trichostrongylus spp., Strongyloides westeri, Parascaris equorum, Oxyuris equi, Trichonema spp., and Anaplocephala spp. were observed. These results coincide with those reported by Felipelli et al. In 2015 and Güiris et al. who observed in horses the presence of Parascasis equorum, Strongyloides westeri, Strongylus edentatus, Oxyuris equi, Strongylus vulgaris and additionally Triodontophorus serratus, Cyathostominae, Habronema muscae, Trichostrongylus axei (Guiris et al., 2010, Felipelli et al., 2015). 


\section{CONCLUSION}

Trichostrongylus spp is the predominant gastrointestinal parasite in donkeys in the Tulancingo Valley. With the results of the present investigation the main parasitosis in donkeys of the Tulancingo Valley has been identified, information that will allow proposing specific treatments for each case this will impact positively on the welfare of the species under study.

\section{ACKNOWLEDGMENTS}

The present research project was carried out with self-financing, so a cordial thank you to the students and professors of the degree in Veterinary Medicine and Animal Science of the Institute of Agricultural Sciences of the Autonomous University of Hidalgo State, for their support and dedication to the fulfillment of the objectives of the present project.

\section{REFERENCES}

BESNÉ MA, Figueroa CJA, Quiroz RH, Ramírez GA, Ramos ME. 2006. Manual de Prácticas de Laboratorio de Parasitología FMVZ. UNAM. México D.F. ISBN: 970-323321-X

BEDOYA MA, Arcila VC, Díaz DA, Reyes EA. 2011. Prevalencia de parásitos gastrointestinales en équidos del municipio de Oiba (Santander). Revista spei domus. 23(7) 19-20. DOI: http://dx.doi.org/10.16925/sp.v11i23.1362.

CARDONA ÁJA, Arroyave VV, Zapata GAF. 2015. Frecuencia de patologías gástricas en burros (Equus africanus asinus) en Córdoba, Colombia. Rev Med Vet. ; (31): 23-34. ISSN 0122-9354 ISSNe 2389-8526. http://www.scielo.org.co/pdf/rmv/n31/n31a03.pdf.

CRIBB NC, Coté NM, Bouré LP, Peregrine AS. 2006. Acute small intestinal obstruction associated with Parascaris equorum infection in young horses: 25 cases. New Zealand Veterinary Journal. 54(6), 338-343. DOI:10.1080/00480169.2006.36721.

FELIPPELLI G, Cruz BC, Gomes LVC, Lopes WDZ, Teixeira WFP, Maciel WG, Buzzolini C, Pimentel CG, Abud BB, Edésio SB, Formigoni BPL, Pereira OA, José da Costa A. 2015. Susceptibility of helminth species from horses against different chemical compounds in Brazil. Veterinary Parasitology. 212(3): 232-238. DOI.10.1111/eve.12018.

FRANCISCO I, Arias M, Cortiñas FJ, Francisco R, Mochales E, Dacal V, Suárez JL, Uriarte J, Morrondo P, Sánchez-Andrade R, Díez-Baños P. And Paz-Silva A. 2009. Intrinsic factors influencing the infection by helminth parasites in horses under an oceanic climate area (NW Spain). Journal of Parasitology Research. 2009:1-5. DOI:10.1155/2009/616173 https://www.hindawi.com/journals/jpr/2009/616173/

GÜIRIS ADM, Rojas HNM, Berovides AV, Sosa PJ, Pérez EME, Cruz AE, Chávez HC, MOGUEL AJA, Jimenez-Coello M, Ortega-Pacheco A. 2010. Biodiversity and distribution of helminths and protozoa in naturally infected horses from the biosphere reserve "La 
Sierra Madre de Chiapas", México. Veterinary Parasitology. 170. 268-27. http://dx.doi.org/10.1016/j.vetpar.2010.02.016.

MATTHEWS JB, Burden FA. 2013. Common helminth infections of donkeys and their control in temperate regions. Equine Vet Educ. 25(9):461-467. DOI: 10.1111/eve.12018.

MATTHEWS JB. 2014. Anthelmintic resistance in equine nematodes. International Journal for Parasitology: Drugs and Drug Resistance, 4: 310-315. DOI: 10.1016/j.jpddr.2014.10.003.

SVENDSEN ED. 1997. Manual profesional del burro. Whittet Books 3ra Edicion, Reino Unido, ISBN: 1873580479 